\title{
High prevalence of familial sarcoidosis in an Irish population
}

\author{
NEIL J BRENNAN, P CREAN, JP LONG, MX FITZGERALD \\ From the Department of Respiratory Medicine, St Vincent's Hospital, Dublin, and the Medical Professorial \\ Unit, University College, Dublin
}

ABSTRACT Previous studies in the Republic of Ireland have demonstrated a high national prevalence of sarcoidosis. Observations in our sarcoid clinic suggested a high prevalence of the disease among siblings and prompted a survey to quantify this phenomenon. The study group comprised 114 index patients with biopsy proved sarcoidosis and a total sibling pool of 534 individuals. Eleven of the index patients $(9.6 \%)$ were found to have at least one sibling with sarcoidosis. Of the 13 siblings thus identified, eight had biopsy proof of the disease, while the remaining five showed highly suggestive clinical and radiological evidence of sarcoidosis. There was no significant difference in the mode of presentation between the sibling pairs or between familial and non-familial cases and there was an equal distribution of like sex and unlike sex pairs. In only two instances was the temporal profile of onset of the disease suggestive of intrafamilial spread of a transmissible agent. The high prevalence of sarcoidosis among siblings reported here $(2 \cdot 4 \%)$ suggests that genetic factors significantly predispose to the development of sarcoidosis and that family members of affected patients should be screened for this disease.

It is recognised that sarcoidosis may affect two or more members of the same family, but such familial occurrence is considered uncommon. For example, a large survey in the United Kingdom found that in only $1.7 \%$ of index cases was another family member affected.' Other, smaller studies have been carried out in various populations but the prevalence data are difficult to compare because of the varying diagnostic and screening criteria and because the total family pool at risk has not been defined. Given that the aetiology of sarcoidosis is unknown it is clear that carefully conducted familial studies could be important in defining genetic and environmental influences in this disease.

This study of familial sarcoidosis in Ireland was undertaken for two reasons. Firstly, screening by mass miniature radiography shows that Ireland has the second highest prevalence of sarcoidosis in Europe (33 per 100000 ), ${ }^{2}$ a figure exceeded only by Sweden. ${ }^{3}$ Secondly, family size in Ireland is larger than in other Northern European countries. These features represent two distinct advantages in investigating and interpreting familial prevalence data.

Address for reprint requests: Professor MX FitzGerald, Medical Professorial Unit, St Vincent's Hospital, Dublin 4, Eire.

Accepted 3 October 1983

\section{Methods}

We reviewed the case notes of all patients with sarcoidosis who had been referred to the department of respiratory medicine during six years; 114 index patients with biopsy proved sarcoidosis were identified. All were issued with a simple questionnaire in which they were asked, firstly, to state the number and sex of their siblings and, secondly, to indicate if any sibling had sarcoidosis or other chest condition. Permission was requested to contact any sibling who had sarcoidosis or similar chest illness. In all such cases the relatives in question were contacted by letter asking for details of their medical history and requesting permission to contact their family doctor. We confined the study to siblings of index cases because of the difficulties in obtaining consistent contemporary information about parents, some of whom were dead.

In addition to the 114 biopsy proved index cases there were 26 patients attending our clinic with typical clinical, radiological, or biochemical features of sarcoidosis but without biopsy proof. For comparison, this group was surveyed in exactly the same way as the patients with biopsy evidence.

We reviewed the presenting clinical features of all index cases and of those siblings with sarcoidosis who were identified in our survey. 
Table 1 Clinical features in familial cases of sarcoidosis (index cases given furst)

\begin{tabular}{|c|c|c|c|c|c|c|c|c|c|c|}
\hline \multirow{2}{*}{$\begin{array}{l}\text { Family } \\
\text { No }\end{array}$} & \multirow[t]{2}{*}{ Sex } & Age & Year & \multirow{2}{*}{$\begin{array}{l}\text { Biopsy } \\
\text { proof }\end{array}$} & \multirow{2}{*}{$\begin{array}{l}\text { Lung } \\
\text { parenchyma } \\
\text { affected }\end{array}$} & \multirow{2}{*}{$\begin{array}{l}\text { Hilar } \\
\text { lymph } \\
\text { nodes }\end{array}$} & \multirow{2}{*}{$\begin{array}{l}\text { Peripheral } \\
\text { lymph } \\
\text { nodes }\end{array}$} & \multicolumn{3}{|c|}{ Other systems affected } \\
\hline & & \multicolumn{2}{|c|}{ at diagnosis } & & & & & Eye & Skin & Other tissue \\
\hline \multirow{2}{*}{1} & $\mathbf{M}$ & 23 & 1968 & + & - & + & + & + & - & ++ \\
\hline & $\mathbf{M}$ & 28 & 1980 & + & + & - & + & - & - & - \\
\hline \multirow{2}{*}{2} & $\mathbf{M}$ & 31 & 1978 & + & + & + & - & + & - & - \\
\hline & $\mathbf{F}$ & 25 & 1981 & + & + & + & - & - & - & - \\
\hline \multirow{2}{*}{3} & $\mathbf{F}$ & 22 & 1976 & + & + & - & + & + & + & + \\
\hline & $\mathbf{M}$ & 32 & 1977 & - & - & + & - & + & + & - \\
\hline \multirow{2}{*}{4} & $\mathbf{M}$ & 39 & 1975 & + & + & - & + & - & - & $++t$ \\
\hline & $\mathbf{M}$ & 34 & 1976 & + & - & + & + & - & - & - \\
\hline \multirow{2}{*}{5} & $\mathbf{M}$ & 37 & 1979 & + & + & + & + & - & + & + \\
\hline & $\mathbf{F}$ & 38 & 1975 & - & - & - & + & + & + & - \\
\hline \multirow{3}{*}{6} & $\mathbf{F}$ & 27 & 1972 & + & + & - & - & - & + & - \\
\hline & $\mathbf{M}$ & 29 & 1982 & - & + & - & + & - & + & + \\
\hline & $\mathbf{M}$ & 26 & 1976 & + & + & + & - & - & - & + \\
\hline \multirow{3}{*}{7} & $\mathbf{M}$ & 24 & 1972 & + & - & + & + & + & - & + \\
\hline & $F$ & 27 & 1978 & - & + & + & - & - & - & - \\
\hline & $\mathbf{M}$ & 33 & 1979 & + & - & + & - & - & - & + \\
\hline \multirow{2}{*}{8} & M & 15 & 1980 & + & + & + & - & - & + & - \\
\hline & $\mathbf{M}$ & 19 & 1981 & + & + & + & - & - & + & - \\
\hline \multirow{2}{*}{9} & $\mathbf{F}$ & 26 & 1979 & + & + & + & - & - & + & - \\
\hline & $\mathbf{F}$ & 27 & 1979 & - & - & + & - & - & + & + \\
\hline \multirow{2}{*}{10} & $\mathbf{F}$ & 16 & 1964 & + & - & - & - & + & - & +++ \\
\hline & $\mathbf{M}$ & 16 & 1963 & + & + & + & + & - & - & - \\
\hline \multirow{2}{*}{11} & $\mathbf{F}$ & 38 & 1980 & + & - & - & - & - & + & + \\
\hline & $\mathbf{M}$ & 36 & 1977 & + & + & + & - & - & - & + \\
\hline
\end{tabular}

* Each + sign indicates a separate clinical feature.

Table 2 Clinical features of familial and non-familial cases of sarcoidosis

\begin{tabular}{|c|c|c|c|c|}
\hline \multirow{2}{*}{$\begin{array}{l}\text { Presenting } \\
\text { feature }\end{array}$} & \multicolumn{3}{|c|}{ No $(\%)$ of index cases } & \multirow{2}{*}{$\begin{array}{l}\text { No }(\%) \text { of } \\
\text { all familial cases } \\
(n=24)\end{array}$} \\
\hline & $\begin{array}{l}\text { Total } \\
(n=114)\end{array}$ & $\begin{array}{l}\text { Non-familial } \\
(n=103)\end{array}$ & $\begin{array}{l}\text { Familial } \\
(n=11)\end{array}$ & \\
\hline $\begin{array}{l}\text { Pulmonary infiltrates } \\
\text { Hilar lymphadenopathy } \\
\text { Ocular lesions } \\
\text { Erythema nodosum } \\
\text { General lymphadenopathy } \\
\text { Hypercalciuria }\end{array}$ & $\begin{array}{l}85(75) \\
79(69) \\
36(32) \\
29(25) \\
25(22) \\
18(16)\end{array}$ & $\begin{array}{l}77(75) \\
73(71) \\
32(31) \\
25(24) \\
21(20) \\
15(15)\end{array}$ & $\begin{array}{l}8(73) \\
6(55) \\
4(36) \\
4(36) \\
4(36) \\
3(27)\end{array}$ & $\begin{array}{r}15(63) \\
16(67) \\
7(29) \\
8(33) \\
10(42) \\
4(17)\end{array}$ \\
\hline
\end{tabular}

There was no significant difference between the groups. Less frequently occurring clinical features are not included because of the small numbers in the familial groups.

\section{Results}

\section{BIOPSY PROVED INDEX CASES}

The 114 index cases comprised 56 females and 58 males, whose ages ranged from 13 to 69 years (mean 29.5 years). Replies to the questionnaire were received from $113(99 \%)$ and a total of 534 siblings were identified. Index patients had a mean of 4.7 (SD 2.8) siblings. Overall there was a slight preponderance of male siblings, with a ratio of $1 \cdot 28$.

Twenty three index patients reported a possible family history of sarcoidosis or other chest complaint in one or more siblings. Of a total of $29 \mathrm{sib}-$ lings thus identified as sarcoid suspects, five failed to reply and 11 proved to have non-sarcoid pulmonary disease. The remaining 13 siblings from 11 families were confirmed as having sarcoidosis. In eight affected siblings the diagnosis of sarcoidosis was based on typical clinical features and was confirmed by positive biopsy findings. In the remaining five cases clinical and radiological features were highly suggestive of sarcoidosis (table 1). Among affected siblings there were four pairs of like sex and six of unlike sex, and one family had four affected members. The pattern of clinical features at the time of diagnosis did not differ between familial and non-familial cases (table 2). In one further family a mother-daughter pair was identified.

In families with more than one affected sibling we sought historic evidence of possible intrafamilial spread of the disease. In most cases it was not possible to construct clear contact histories because of 
the retrospective nature of the study and the great variability in the frequency and duration of sibling contact. In one family, however, two sisters developed the disease within three weeks of each other. In another family a newly diagnosed index patient went to visit her brother in Canada, whom she had not seen for 18 months. He developed erythema nodosum and bilateral hilar lymphadenopathy 10 days after her arrival and was subsequently proved to have sarcoidosis.

\section{NON-BIOPSY PROVED INDEX CASES}

This group comprised 26 index cases with a total sibling pool of 128 individuals. We identified three biopsy proved siblings with sarcoidosis from two families.

\section{Discussion}

The outstanding feature of this study is that $9.6 \%$ of our patients with sarcoidosis had at least one sibling who was affected by the disease. This is in striking contrast to previous studies in the United Kingdom and Europe, ${ }^{1-9}$ in which a much lower prevalence of familial sarcoidosis was reported. In many cases direct comparison with our results is difficult because of variations in the methods used to screen patients or relatives. In many previous studies analysis of data does not permit definition of the total sibling pool and one cannot therefore estimate the risk to siblings in these studies. For comparison with our own results, however, we have reviewed several of these reports and calculated the percentage of index cases with an affected sibling (table 3 ). In most European studies only about $1 \%$ of index cases had an affected sibling. We could find only one study where the study population and methods could be directly compared with our own. In this study, by Headings et al ${ }^{10}$ in United States blacks, the findings were very similar to our own in terms of study size, sibling pool at risk, and the frequency with which siblings were affected (table 3 ). This concurrence in culturally and ethnically distinct study groups is remarkable, although it is known that both populations have a particularly high prevalence of sarcoidosis. If we pool the results of these two studies we can estimate that about $10 \%$ of index patients with sarcoidosis will have a positive family history and that about one in $40(2.4 \%)$ of the siblings will be found to be affected. These findings for the prevalence of familial sarcoidosis may underestimate the true figure since both studies relied only on questionnaire; screening procedures such as chest radiography might be expected to detect further cases since the disease is often asymptomatic.

The phenomenon of familial aggregration of sarcoidosis may result from genetic or environmental factors or both. There is a considerable body of data to support a genetic contribution. In France natives of Martinique have a higher prevalence of sarcoidosis than the indigenous French population and, in addition, familial disease occurs in $5.4 \%$ of the islanders but in only $1.2 \%$ of Europeans. ${ }^{5}$ Similarly, the Irish in London are reported to have a higher prevalence of sarcoidosis than native Londoners. ${ }^{11}$ Furthermore, the comprehensive review by the British Thoracic and Tuberculosis Association of familial sarcoidosis ${ }^{12}$ showed $(a)$ a preponderance of like sex over unlike sex pairs among both sibling and parent-child associations; $(b)$ an excess of monozygotic over dizygotic twins concordant for sarcoidosis; and (c) an excess of mother-child over father-child associations. On the basis of an analysis of their sarcoidosis population, James et al ${ }^{1}$ suggested a recessive mode of inheritance but Headings $e t a^{10}$ favoured a multigenic pattern of inheritance. So far, attempts to demonstrate a genetic linkage by means of HLA marker studies have been disappointing and have produced conflicting results. ${ }^{13-20}$ It has been claimed,

Table 3 Frequency of sarcoidosis in siblings of index cases*

\begin{tabular}{|c|c|c|c|c|}
\hline $\begin{array}{l}\text { Population } \\
\text { studied }\end{array}$ & $\begin{array}{l}\text { Total index } \\
\text { cases }\end{array}$ & $\begin{array}{l}\text { No }(\%) \text { of } \\
\text { index cases with } \\
\text { affected sibling }\end{array}$ & $\begin{array}{l}\text { Total } \\
\text { sibling pool }\end{array}$ & $\begin{array}{l}\text { \% of siblings } \\
\text { affected }\end{array}$ \\
\hline $\begin{array}{l}\text { UK }^{14} \\
\text { France }^{5} \\
\text { Germany }^{612} \\
\text { USSR }^{7} \\
\text { Italy }^{8} \\
\text { Hungary } \\
\text { USA } \\
\text { USA }^{40} \text { (largely black) } \\
\text { Ireland (present study) }\end{array}$ & $\begin{array}{r}537 \\
645 \\
2471 \\
680 \\
107 \\
629 \\
150 \\
80 \\
114\end{array}$ & $\begin{array}{rl}4 & (0 \cdot 7) \\
3 & 0 \cdot 5 \\
30 & 1 \cdot 2 \\
1 & 0 \cdot 1 \\
1 & 1 \cdot 0) \\
6 & 1 \cdot 0) \\
7 & (4 \cdot 6) \\
8(10 \cdot 0) & \\
11 & (9 \cdot 6)\end{array}$ & $\begin{array}{l}381 \\
534\end{array}$ & $\begin{array}{l}2 \cdot 4 \\
2 \cdot 4\end{array}$ \\
\hline
\end{tabular}

*For purposes of comparison data from previous studies have been reanalysed in order to estimate the percentage of index cases with an affected sibling and the percentage of affected siblings in the total sibling pool. 
however, that patients with HLA-B8 who develop sarcoidosis are more likely to have arthritis or erythema nodosum or both ${ }^{21}$ and that the sarcoidosis is more likely to resolve spontaneously. ${ }^{22}$

By contrast, few data exist to implicate environmental factors in this disease. Clearly, the demonstration of case clustering in time or place among related or unrelated subjects would favour an environmental contribution. We have described two families which show such temporal or geographic relationships. A recent report describes a cluster of four cases - two sisters and two unrelated subjects. ${ }^{23}$ While the authors note the paucity of similar published reports close temporal relationships have nevertheless been found in both husband-wife pairs $^{2425}$ and in siblings. ${ }^{562627}$ The BTTA study $^{12}$ failed to demonstrate close temporal relationships among affected family members. It is important to emphasise, however, that such a retrospective survey cannot be expected to document accurately the temporal or geographical clustering of cases. This could be determined only by a prospective, detailed screening of all close contacts of patients with sarcoidosis.

Irrespective of the varying contributions of genetic and environmental factors, the clear implication of our study is that siblings of patients with sarcoidosis should be screened for the disease. Our data and those of Headings et al, ${ }^{10}$ based on questionnaires, suggest that such screening would yield positive results in at least $2.4 \%$ of subjects screened. This yield approximates closely to that obtained in screening close contacts of patients with tuberculosis, $3.5 \%$ of whom will have that disease. ${ }^{28}$ Incorporation of chest radiography in such screening might be expected to increase even further the numbers of those found to have sarcoidosis, given the asymptomatic behaviour of the disease in some individuals. Detection of subclinical cases of sarcoidosis might help to prevent serious sequelae in that small subgroup of patients destined to develop progressive pulmonary fibrosis. A careful prospective epidemiological study of familial sarcoidosis combined with HLA marker studies might help to delineate the relative contributions of genetic and environmental factors in the pathogenesis of sarcoidosis.

\section{References}

' James DG, Neville E, Piyasena KHG, Walker AN, Hamlyn AN. Possible genetic influences in familial sarcoidosis. Postgrad Med J 1974;50:664-70.

${ }^{2}$ Logan J. Prevalence of sarcoidosis in the Irish Republic. Acta Med Scand 1964;425,suppl:126.

${ }^{3}$ Bauer HJ, Lofgren S. International study of pulmonary sarcoidosis in mass chest radiography. Acta Med Scand 1964;425,suppl:103-5.

${ }^{4}$ Sharma OP, Neville E, Walker AN, James DG. Familial sarcoidosis; a possible genetic influence. Ann NY Acad Sci 1974;278:386-400.

${ }^{5}$ Turiaf J, Battesti J-P, Jeanjean Y, Fourestier V. Sarcoidose familiale: 26 cas dans 12 familles. Nouv Presse Med 1978;7:913-5.

- Jorgensen G. Untersuchungen zur Genetik der Sarkoidose. Heidelberg: Huthig Verlag, 1965.

${ }^{7}$ Kostina ZI, Volkova KI. Familial sarcoidosis. Klin Med Mosk 1978;56:129-31.

${ }^{8}$ Bisetti A, Livi E. Frequency and characters of familial pulmonary sarcoidosis. Zeitschrift fuer Erkrankungen der Atmungsorgane 1977;149:212-8.

9 Vezendi S, Mandi L. Family occurrence of sarcoidosis. Zeitschrift fuer Erkrankungen der Atmungsorgane 1977;149:274-5.

${ }^{10}$ Headings VE, Weston D, Young RC, Hackney RL. Familial sarcoidosis with multiple occurrences in eleven families: a possible mechanism of inheritance. Ann NY Acad Sci 1976;278:377-85.

${ }^{11}$ Hall G, Naish P, Sharma OP, Doe W, James DG. The epidemiology of sarcoidosis. Postgrad Med J 1969;45:241-50.

${ }^{12}$ British Thoracic and Tuberculosis Association. Familial associations in sarcoidosis. Tubercle 1973;54:87-98.

${ }^{13}$ Hedfors E, Möller E. HL-A antigens in sarcoidosis. Tissue Antigens 1973;3:95-8.

${ }^{14}$ Möller E, Hedfors E, Wiman L-G. HL-A genotypes and MLR in familial sarcoidosis. Tissue Antigens 1974;4:299-305.

is Kueppers F, Mueller-Eckhardt C, Heinrich D, Schwab B, Brackertz D. HL-A antigens of patients with sarcoidosis. Tissue Antigens 1974;4:56-8.

${ }^{16}$ Persson I, Ryder LP, Nielsen LS, Svejgaard A. The HLA-A7 histocompatibility antigen in sarcoidosis in relation to tuberculin sensitivity. Tissue Antigens 1975;6:50-3.

${ }^{17}$ Brewerton DA, Cockburn C, James DCO, James DG, Neville E. HLA antigens in sarcoidosis. Clin Exp Immunol 1977;27:227-9.

${ }^{18}$ McIntyre JA, McKee KT, Loadholt CB, Mercurio S, Lin I. Increased HLA-B7 antigen frequency in South Carolina Blacks in association with sarcoidosis. Transplant Proc 1977;9,suppl 1:173-6.

${ }^{19}$ Eisenberg H, Terasaki PI, Sharma OP, Mickey MR. HLA association studies in black sarcoidosis patients. Tissue Antigens 1978;11:484-6.

${ }^{20}$ Al-Arif L, Goldstein RA, Affronti LF, Janicki BW, Foellmer JW. HLA antigens and sarcoidosis in a North American black population. In: Williams WJ, Davies $\mathrm{BH}$, eds. Proceedings of the VIIIth international conference on sarcoidosis. Cardiff: Alpha Omega, 1980:206-12.

${ }^{21}$ Neville E, James DG, Brewerton DA, James DCO, Cockburn C, Fenichal B. HLA antigens and clinical features of sarcoidosis. In: Williams WJ, Davies BH, eds. Proceedings of the VIIIth international conference on sarcoidosis. Cardiff: Alpha Omega, 1980:201-5.

22 Smith MJ, Turton CWG, Mitchell DN, Turner-Warwick M, Morris LM, Fawler SD. Association of HLA B8 with spontaneous resolution in sarcoidosis. Thorax $1981 ; 36: 296-8$.

${ }^{23}$ Stewart IC, Davidson N McD. Clustering of sarcoidosis. Thorax 1982;37:398-9. 
${ }^{24}$ Renner RR, Lahiri M, Bragoli AJ. Sarcoidosis in husband and wife. NY State J Med 1977;77:118-9.

${ }^{25}$ Harrison PV, Ive FA. Sarcoidosis in husband and wife. NY State J Med 1978;78:2130.

${ }^{26}$ Sharma OP, Johnson CS, Balchum OJ. Familial sarcoidosis-report of four siblings with acute sarcoidosis. Am Rev Respir Dis 1971;104:255-7.
${ }^{27}$ Ito Y, Ogima I, Kinoshita Y. Familial sarcoidosis in Japan. In: Iwai H, Hosoda Y, eds. Proceedings of the VIth international conference on sarcoidosis. Tokyo: Tokyo University Press, 1974:30-3.

${ }^{28}$ Davies BH. Infectivity of tuberculosis. Thorax 1980;35:481-2. 